Takahiko Horiuchi • Hiroaki Nishizaka

Hiroshi Tsukamoto • Shin-ichi Harashima

Takuya Sawabe - Chika Morita • Yoshiyuki Niho

\title{
An Ncol polymorphism in the human complement component 7 (C7) gene
}

\begin{abstract}
A novel polymorphic site has been found in the $3^{\prime}$ untranslated region (UTR) of the human complement component 7 (C7) gene. The polymorphic site at 14-bp downstream from the TAG stop codon was either C or A (Nco I-digested), with allele frequencies of 0.660 and 0.340 . This NcoI polymorphism would be useful to perform a DNA marker haplotype study in patients with deficiencies of the complement genes, such as $C 6, C 7, C 9$, which are located closely on chromosome $5 \mathrm{p} 13$.
\end{abstract}

Key words $\mathrm{C} 7 \cdot \mathrm{NcoI} \cdot$ Polymorphism $\cdot 3^{\prime}$-UTR

\section{Introduction}

The human complement component 7 (C7) is one of five constituents of the membrane attack complex (MAC) of the complement system. The formation of MAC on the target pathogens results in the formation of transmembrane pores that eventually leads to lysis of targets. C7 protein consists of 821 amino acid residues and is structurally similar to the other members of MAC; C6, C8 $\alpha, \mathrm{C} 8 \beta$, and C9 (DiScipio et al. 1988, Hobart et al. 1995). The genes for $C 7$, as well as those for $C 6$ and $C 9$, are located closely on chromosome 5 p13 (Setién et al. 1993). Recently, the molecular bases of the deficiencies for these genes have been described (Nishizaka et al. 1996a, 1996b; Kojima et al. 1998; Horiuchi et al. 1998, 1999). In particular, C9 deficiency is very common in Japanese, estimated to be one homozygote in 1000 (Hayama et al. 1989). In the present study, we found an

T. Horiuchi $(\bowtie) \cdot H$. Nishizaka $\cdot$ H. Tsukamoto $\cdot$ S. Harashima

T. Sawabe $\cdot$ C. Morita $\cdot$ Y. Niho

First Department of Internal Medicine, Faculty of Medicine, Kyushu

University, Fukuoka 812-8582, Japan

Tel. +81-92-642-5233; Fax +81-92-642-5247

e-mail: horiuchi@intmed1.med.kyushu-u.ac.jp
NcoI polymorphism in the $3^{\prime}$ untranslated region (UTR) of the $C 7$ gene. This polymorphism would be useful to perform a DNA marker haplotype study in patients with deficiencies of these complement genes.

\section{Polymorphism and allele frequency}

Primers for the polymerase chain reaction (PCR)

For PCR, we used the following primers:

C7-ex17F 5'-CTCCACAATGTACCATTAAGC-3'

C7-ex17R 5'-TGTGCAGATGTTTTCACTCAG-3'

NcoI polymorphism. The fragment size of the PCR product is 293 bp (Nishizaka et al. 1996b). NcoI digestion produces a 293-bp undigested fragment in the A1 allele that lacks the $\mathrm{Nco}$ I site, while in the A2 allele having the $\mathrm{NcoI}$ restriction site, two fragments, with lengths of 236 and $57 \mathrm{bp}$, are generated.

Chromosomal localization. The human $C 7$ gene has been assigned to chromosome $5 \mathrm{p} 13$.

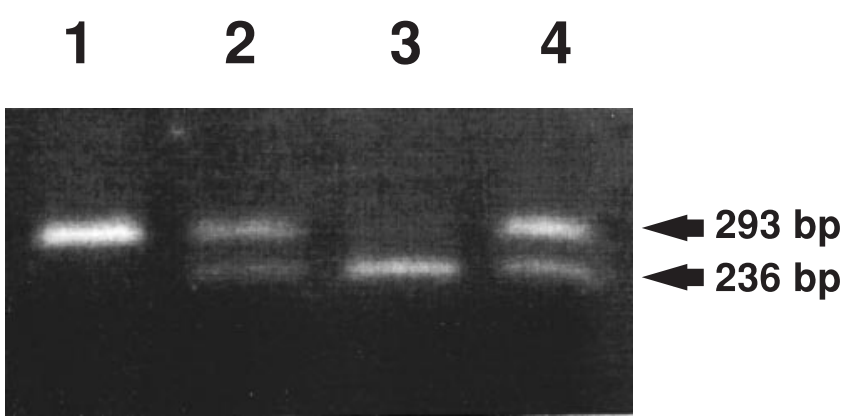

Fig. 1. NcoI restriction fragment length polymorphism (RFLP), NcoI digests were electrophoresed on $1.5 \%$ agarose gel. Lane 1 indicates a homozygote for A1; lanes 2 and 4 are heterozygotes for A1/A2; lane 3 indicates a homozygote for A2. The smaller NcoI-digested fragments in the A2 allele (lanes 2, 3, and 4) were not clearly observed in this gel condition 
Table 1. Allele frequencies of NcoI polymorphisms of the human $C 7$ gene among 47 Japanese

\begin{tabular}{lllll}
\hline Allele & Nucleotide & Fragments (bp) & Frequency & Heterozygosity \\
\hline A1 & C & 293 & 0.660 & 0.468 \\
A2 & A & 236,57 & 0.340 & \\
\hline
\end{tabular}

Mendelian inheritance. Mendelian inheritance was confirmed in two families.

Other comments. The primers, C7-ex17F and C7-ex17R, were intron-based exon-specific primers for exon 17 of the $C 7$ gene. In the process of screening for $C 7$ gene mutations in patients with C7 deficiency, using PCR-single-strand conformation polymorphism (SSCP) analysis, we identified this $N c o$ I polymorphism. The nucleotide sequence at 14-bp downstream from the TAG stop codon was either C or A (NcoI-digested). PCR was carried out in a total volume of $25 \mu \mathrm{l}$ reaction mixture, containing $1 \mu \mathrm{g}$ genomic DNA, $2 \mu \mathrm{M}$ of each primers, $200 \mu \mathrm{M}$ dNTP, and 2.5 U Taq polymerase, and the standard buffer provided by the manufacturer (Perkin Elmer, Norwalk, CT, USA). Reactions were conducted for 30 cycles consisting of $1 \mathrm{~min}$ at $95^{\circ} \mathrm{C}$ and $2 \mathrm{~min}$ at $60^{\circ} \mathrm{C}$, using a thermal cycler (PJ2000; Perkin Elmer). After the digestion of the PCR products with $N c o$ I, the digests were subjected to $1.5 \%$ agarose gel electrophoresis and were visualized with ethidium bromide.

\section{References}

DiScipio RG, Chakravarti DN, Müller-Eberhard HJ, Fey GH (1988) The structure of human complement component $\mathrm{C} 7$ and the $\mathrm{C} 5 \mathrm{~b}-7$ complex. J Biol Chem 263:549-560

Hayama K, Sugai N, Tanaka S, Lee S, Kikuchi H, Ito J, Suzuki J, Nagata Y, Kondo H, Harayama O, Tuzuki K, Yoshida S, Fujita M, Ohmori F, Kawai T, Akagaki Y, Inai S (1989) High incidence of C9 deficiency throughout Japan: there are no significant differences in incidence among eight areas of Japan. Int Arch Allergy Appl Immunol 90:400-404

Hobart MJ, Fernie BA, DiScipio RG (1995) Structure of the human C7 gene and comparison with the $C 6, C 8 A, C 8 B$, and $C 9$ genes. J Immunol 154:5188-5194

Horiuchi T, Nishizaka H, Kojima T, Sawabe T, Niho Y, Schneider PM, Inaba S, Sakai K, Hayashi K, Hashimura C, Fukumori Y (1998) A non-sense mutation at Arg95 is predominant in complement 9 deficiency in Japanese. J Immunol 160:1509-1513

Horiuchi T, Ferrer JM, Serra P, Matamoros N, Lópoz-Trascasa M, Hashimura C, Niho Y (1999) A novel nonsense mutation at Glu-631 in a Spanish family with complement component 7 deficiency. J Hum Genet 44:215-218

Kojima T, Horiuchi T, Nishizaka H, Fukumori Y, Amano T, Nagasawa K, Niho Y, Hayashi K (1998) Genetic basis of human C8 $\alpha-\gamma$ deficiency. J Immunol 161:3726-3766

Nishizaka H, Horiuchi T, Zhu Z-B, Fukumori Y, Nagasawa K, Hayashi K, Krumdieck R, Cobbs CG, Higuchi M, Yasunaga S, Niho Y, Volanakis JE (1996a) Molecular bases for inherited human complement component C6 deficiency in two unrelated individuals. J Immunol 156:2309-2315

Nishizaka H, Horiuchi T, Zhu Z-B, Fukumori Y, Volanakis JE (1996b) Genetic bases of human complement C7 deficiency. J Immunol 157:4239-4243

Setién F, Alvarez V, Coto E, DiScipio RG, López-Larrera C (1993) A physical map of the human complement component $C 6, C 7$, and $C 9$ genes. Immunogenetics 38:341-344 